\title{
PENGARUH PENAMBAHAN LIMBAH PEMBAKARAN BATUBARA (FLY ASH) EX PLTU RUM PADA CAMPURAN BETON
}

\author{
Mufti Amir Sultan ${ }^{1)}$, Imran 2), Muhammad Faujan ${ }^{3)}$ \\ Program Studi Teknik Sipil, Universitas Khairun \\ email: muftiasltn@unkhair.ac.id ${ }^{1}$, namakuimo@ hotmail.com $^{2}$, \\ faujanlaher007@gmail.com ${ }^{3)}$
}

DOI: http://dx.doi.org/10.29103/tj.v9i2.186

(Received: Maret 2019 / Revised: April 2019 / Accepted: May 2019)

\begin{abstract}
Abstrak
Beton adalah material yang umum digunakan dalam dunia pembangunan infrastruktur seperti gedung, jembatan, jalan raya, dan insfrastruktur lainnya. PLTU Rum Tidore Kepulauan menggunakan batubara sebagai bahan bakar, yang menghasilkan produk sampingan berupa limbah abu terbang (fly ash). Tujuan dari penelitian ini adalah untuk mengetahui efek penambahan fly ash dalam campuran beton. Komposisi fly ash yang dicampurkan pada beton dengan variasi kadar $10 \%$ sampai 30\% dengan kenaikan 5\% terhadap berat semen. Beton tanpa penambahan fly ash sebagai benda uji kontrol. Benda uji berukuran tinggi $30 \mathrm{~cm}$ dan diameter $15 \mathrm{~cm}$ berbentuk silinder, berjumlah 90 buah. Hasil penelitian menunjukan nilai kuat tekan optimum terjadi pada variasi fly ash $20 \%$ sebesar 29,43 Mpa yang meningkatkan kuat tekan sebesar 26,45\% dari beton tanpa bahan tambah fly ash.
\end{abstract}

Kata kunci: Beton, Kuat Tekan, PLTU, Rum, Fly Ash

\begin{abstract}
Concrete is a material commonly used in the world of infrastructure development such as buildings, bridges, highways, and other infrastructure. The Rum Tidore Islands PLTU uses coal as fuel, which produces a by-product in the form of fly ash. The purpose of this study was to determine the effect of adding fly ash in concrete mixtures. The composition of fly ash mixed with concrete with varying levels of $10 \%$ to $30 \%$ with a $5 \%$ increase in the weight of cement. Concrete without the addition of fly ash as a control specimen. The specimens are $30 \mathrm{~cm}$ high and $15 \mathrm{~cm}$ in diameter cylindrical, totaling 90 pieces. The results showed that the optimum compressive strength occurred at $20 \%$ fly ash variation of $29.43 \mathrm{MPa}$ which increased the compressive strength by $26.45 \%$ from concrete without material added fly ash.
\end{abstract}

Keywords: Concrete, Compressive Strength, PLTU, Rum, Fly Ash

\section{Latar Belakang}

Pekerjaan struktur bangunan sering menggunakan bahan beton, pilihan penggunaan beton sebagai bahan konstruksi ini dikarenakan beton mempunyai beberapa keunggulan yang dibandingkan bahan lain, di antaranya beton relatif lebih terjangkau karena bahan penyusunnya didapat dari bahan lokal, mudah dalam pengerjaan dan perawatannya. 
PLTU Rum di Kota Tidore Kepulauan memanfaatkan batubara sebagai sumber energi. Abu batubara adalah produksi sampingan dari pembakaran batubara. Limbah hasil pembakaran batubara berupa fly ash dan bottom ash (FABA). Fly ash pada umumnya diperoleh dari tangkapan cerobong asap pembakaran batubara yang menghasilkan energi sedangkan bottom ash diperoleh dari tungku pembakaran batubara pada bagian bawah.

Limbah dari pembakaran batubara dapat menyebabkan polusi lingkungan berupa pencemaran udara dan air tanah. Limbah ini mengandung kandungan oksida logam berat yang akan mengalami pelindihan secara alami dan mencemaran lingkungan maka limbah batubara ini dikategorikan sebagai limbah B3. Penanganan limbah di PLTU Rum dilakukan dengan cara meletakkan pada lahan terbuka, penanganan ini belum efektif karena dapat menimbulkan bahaya bagi masyarakat dan lingkungan sekitar, karena logam-logam pada abu batubara dapat ter-estrak dan terbawa ke perairan serta tertiup angin sehingga dapat mengganggu pernapasan, oleh karena itu penting adanya pemanfaatan limbah batubara yang dihasilkan dari hasil pembakaran PLTU Rum Kota Tidore Kepulauan. Salah satu pemanfaatan fly ash yaitu pada bidang konstruksi, seperti sebagai bahan tambah atau additive dalam campuran beton.

Abu terbang (fly ash) adalah merupakan salah satu hasil produksi sampingan pembakaran batubara, yang dialirkan dari ruang pembakaran melalui ketel berupa semburan asap, yang telah digunakan sebagai bahan campuran pada beton. Abu terbang (fly ash) sendiri memiliki kemampuan mengikat seperti halnya semen. Apabila ada air dan ukuran partikelnya yang halus, oksida silika yang ada dalam fly ash akan bereaksi secara kimia dengan kalsium hidroksida yang menghasilkan zat yang memiliki kemampuan mengikat.

SNI S-15-1990-F menjelaskan spesifikasi abu terbang sebagai additive/bahan tambahan dalam campuran beton. SNI membagi tiga jenis abu terbang, yaitu kelas F, kelas $\mathrm{N}$ dan kelas $\mathrm{C}$. Persyaratan kimia abu terbang menurut SNI 2460-2014 diperlihatkan pada Tabel 1.

Tabel 1 Persyaratak Kimia Abu Terbang

\begin{tabular}{llccc}
\hline \multirow{2}{*}{ No } & \multirow{2}{*}{ Uraian } & \multicolumn{3}{c}{ kelas } \\
\cline { 3 - 5 } & & $\mathbf{N}$ & $\mathbf{F}$ & $\mathbf{C}$ \\
\hline 1 & $\mathrm{SiO}_{2}+\mathrm{Fe}_{2} \mathrm{O}_{3}+\mathrm{Al}_{2} \mathrm{O}_{3}, \mathrm{Min}, \%$ & 70 & 70 & 50 \\
\hline 2 & $\mathrm{SO}_{3}, \mathrm{Maks} \%$ & 4 & 5 & 5 \\
\hline 3 & Kadar Air, Maks, \% & 3 & 3 & 3 \\
\hline 4 & Hilang Pijar, Maks, \% & 10 & 6 & 6 \\
\hline
\end{tabular}

Penggunaan bahan tambah mineral atau additive dapat memperbaiki kinerja beton salah satunya mempertinggi kekuatan beton (Mulyono, 2004). Pemanfaatan fly ash sebagai additive atau bahan tambah dalam campuran beton telah banyak diteliti seperti: penambahan fly ash dalam campuran beton, di mana nilai kuat tekan yang dihasilkan mengalami peningkatan seiring dengan bertambahnya proporsi abu terbang, namun dalam penelitian kuat tekan beton maksimum belum 
tercapai (Suarnita, 2011). Penambahan fly ash dengan berbagai variasi pada campuran beton menghasilkan kuat tekan tertinggi dengan usia beton 28 hari pada kadar 5\% dengan peningkatan kuat tekan beton $99,15 \%$ dari beton tanpa penambahan fly ash (Danasi dan Lisantono, 2015). Penggunaan fly ash sebagai limbah dari PLTU Sijantang Sawahluntoh dengan menambahkan ke dalam campuran beton antara 5\% sampai 25\%, peningkatan kuat tekan antara 5,195\% sampai 16,535\% dari beton tanpa fly ash atau beton normal (Armeyn, 2014).

Penelitian dengan menambahkan fly ash dalam campuran beton yang bermutu tinggi sebagai pengganti semen, menyatakan bahwa semakin besar konsentrasi fly ash dalam campuran beton maka akan meningkatkan nilai kuat tekan, namun kuat tekan akan menurun apabila penggunaan fly ash terlalu banyak (Ervianto et al, 2016). Penelitian dengan menggunakan fly ash sebagai pengganti semen terhadap kuat tekan beton. Konsentrasi fly ash yang digunakan bervariasi, mulai dari $5 \%$ sampai $12,5 \%$ dengan interval $2,5 \%$. Kuat tekan optimum pada penggunaan fly ash dengan kadar 12,5\%, adalah 231,04 Kg/cm2 (Setiawati, 2018). Penambahan fly ash dan superplasticizer secara bersama-sama dalam campuran beton dengan mutu tinggi pada kadar masing-masing 2\% dapat memperbaiki kuat tekan beton mutu tinggi. Kuat tekan maksimum adalah 57,11 MPa (Pujianto, 2010). Penelitian dengan penambahan fly ash dalam campuran senilai $30 \%$ dengan kenaikan tiap 10\% sampai 70\% untuk mengetahui kuat tarik belah beton. Hasil penelitian menghasilkan kuat tarik belah optimum pada persentase $30 \%$ dengan nilai 3,21 MPa. Kuat tarik belah minimum pada konsentrasi $70 \%$ dengan nilai kuat tarik belah $0,82 \mathrm{MPa}$ (Marthinus dkk, 2015). Penambahan fly ash dalam campuran beton berkinerjia tinggi dengan konsentrasi 10\%, 25\%, dan 50\% dapat memperbaiki kinerja beton pada kondisi normal maupun kondisi agresif (Gopalakrishnan, 2018). Penggunaan fly ash tipe $\mathrm{F}$ dan $\mathrm{C}$ pada campuran beton mempunyai kekuatan tekan jangka panjang yang lebih tinggi, karena sifat pozzolan dari abu terbang dan FAS yang lebih rendah. Juga, kandungan rongga permeabel air dan absorpsi lebih rendah untuk campuran beton dengan fly ash, ini menunjukkan bahwa daya tahan beton yang telah ditambahkan fly ash jauh lebih baik daripada campuran beton yang tidak menggunakan fly ash (Crouch et al, 2007). Pemanfaatan fly ash dalam membuat campuran mortar yang dirancang berdasarkan berat memberikan penghematan biaya 50\% hingga $60 \%$ sementara dengan metode berat memberikan penghematan biaya $9 \%$ hingga $16 \%$, pada penelitian ini fly ash digunakan sebagai subtitusi pasir (Jain dan Islam, 2013). Penambahan super-fine fly asha secara signifikan dapat meningkatkan sifat mekanik beton dan meningkatkan ketahanan permeabilitas ion klorida (Feng dan Ma Gl, 2015)

\section{Metode Penelitian}

\subsection{Kuat Tekan beton dan Modulus Elastis}

Beton yang baik adalah jika beton tersebut memiliki kuat tekan yang tinggi, dengan kata lain mutu beton ditinjau hanya dari kuat tekannya saja (Tjokrodimulyo, 1996). Kuat tekan beton mengidentifikasikan mutu dari sebuah struktur, semakin tinggi tingkat kekuatan struktur yang diinginkan, semakin tinggi pula mutu beton yang dibutuhkan. Pengujian kuat tekan beton menggunakan benda uji berbentuk kubus $15 \mathrm{~cm}$ x $15 \mathrm{~cm}$ x $15 \mathrm{~cm}$ atau silinder diameter $15 \mathrm{~cm}$ 
dan tinggi $30 \mathrm{~cm}$. Beban P (Peak Force) dari pembacaan jarum yang ditunjukan oleh mesin compression strength atau kuat tekan yaitu angka tertinggi yang ditunjukan sebelum sampel retak, pecah atau hancur, besar kuat tekan beton dihitung dengan menggunakan Persamaan (1).

$$
f^{\prime} c=\frac{P}{A}
$$

di mana:

$$
\begin{aligned}
& \mathrm{P}=\text { beban tekan }(\mathrm{kg}) \\
& \mathrm{A}=\text { luas bidang tekan }\left(\mathrm{mm}^{2}\right)
\end{aligned}
$$

Modulus elastisitas beton adalah kemiringan kurva antara teganganregangan di dalam daerah elastis linier, karena kemiringan mempunyai satuan tegangan dibagi dengan regangan, maka modulus elastisitas mempunyai satuan yang sama dengan tegangan. Modulus elastisitas beton tergantung pada modulus elastisitas agregat dan pasta, dalam perhitungan struktur modulus elastisitas dapat dihitung dengan Persamaan 2 sebagai berikut:

$$
E=\frac{\sigma}{\varepsilon}
$$

di mana:

$$
\begin{aligned}
& \mathrm{E}=\text { modulus elastisitas }(\mathrm{MPa}), \\
& \mathcal{E}=\text { regangan aksial, } \\
& \sigma=\text { tegangan aksial }(\mathrm{MPa})
\end{aligned}
$$

\subsection{Tahapan pelaksanaan penelitian}

Penelitian dilakukan di Laboratorium Struktur dan Bahan, Jurusan Teknik Sipil, Fakultas Teknik Universitas Khairun, dalam penelitian ini dibuat benda uji berbentuk silinder untuk pengujian kuat tekan.

Pengujian yang dilaksanakan dalam penelitian ini berupa pengujian bahan, pengujian beton segar dan pengujian beton keras (pengujian kuat tekan). Bahan tambah fly ash yang akan digunakan dengan variasi campuran 0\%, 10\%, 15\%, $20 \%$, 25, dan $30 \%$ terhadap berat semen sebagai penentuan kuat tekan optimal dengan kuat tekan yang direncanakan fc'sebesar $25 \mathrm{MPa}$.

\subsection{Persiapan dan Survei Lokasi Pengambilan Material}

Lokasi pengambilan material agregat kasar, agregat halus dan fly ash seperti diperlihatkan pada gambar 1 dan gambar 2, adapun lokasi tersebut adalah sebagai berikut:

a. Kelurahan Tubo Kecamatan Ternate Utara Kota Ternate, adalah lokasi yang dijadikan sebagai sumber pengambilan bahan baku agregat kasar (batu pecah).

b. Kelurahan Togafo, Kecamatan Ternate Pulau Kota Ternate, adalah lokasi yang dijadikan sebagai sumber pengambilan bahan baku agregat halus (pasir).

c. Abu terbang (fly ash) yang yang digunakan sebagai bahan tambah berasal dari hasil pembakaran PLTU Rum Kota Tidore Kepulauan 


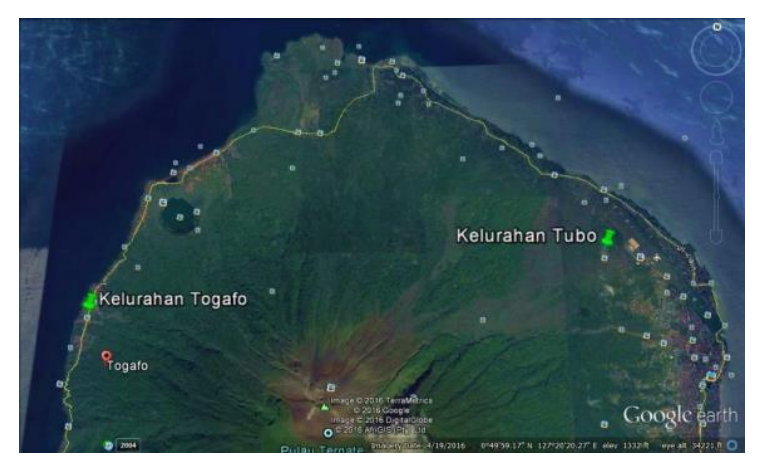

Gambar 1 Lokasi Pengambilan Agregat Kasar (batu pecah) dan Agregat Halus

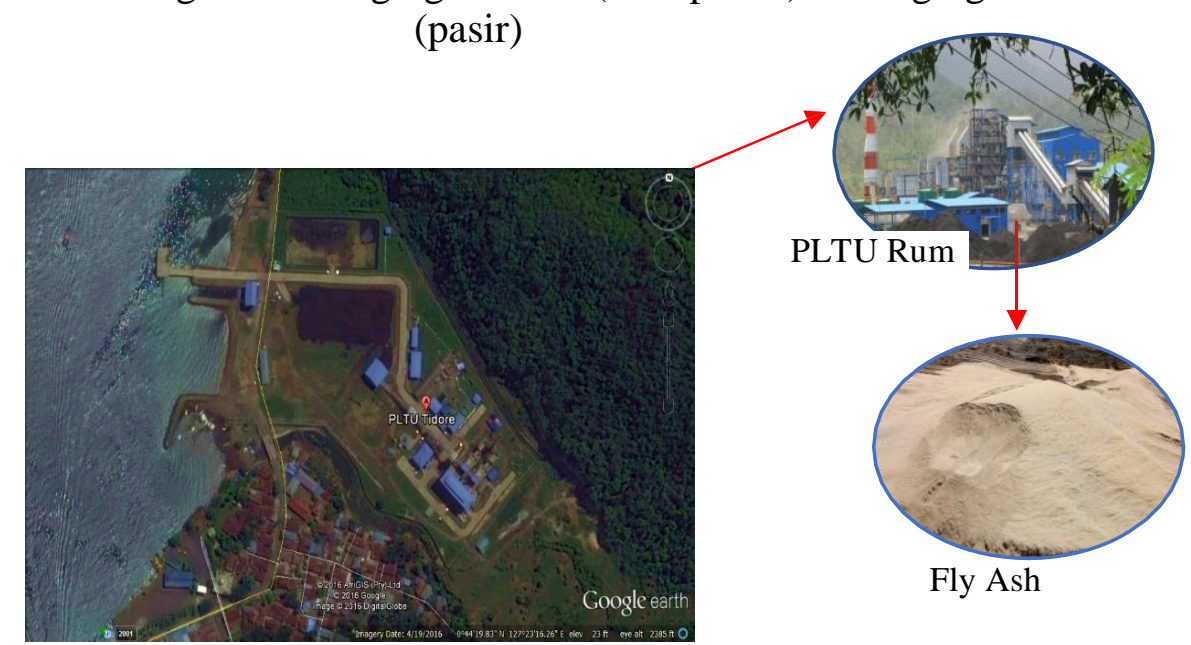

Gambar 2 Lokasi Pengambilan Fly Ash

\subsection{Benda Uji}

Penelitian ini menggunakan 90 buah benda uji berbentuk silinder berdiameter $15 \mathrm{~cm}$ dengan tinggi $30 \mathrm{~cm}$. Dengan penambahan variasi fly ash untuk menentukan nilai kuat tekan terhadap persentasi fly ash dari berat semen. Variasi benda uji seperti pada Tabel 2

Tabel 2 Benda uji dan variasi penggunn fly ash

\begin{tabular}{cccc}
\hline No & Kode Benda Uji & $\begin{array}{c}\text { Fly Ash } \\
(\%)\end{array}$ & $\begin{array}{c}\text { Jumlah Benda Uji } \\
\text { (Buah) }\end{array}$ \\
\hline 1 & $\mathrm{BN}_{1}$ & 0 & 15 \\
\hline 2 & $\mathrm{BA}_{10}$ & 10 & 15 \\
\hline 3 & $\mathrm{BA}_{15}$ & 15 & 15 \\
\hline 4 & $\mathrm{BA}_{20}$ & 20 & 15 \\
\hline 5 & $\mathrm{BA}_{25}$ & 25 & 15 \\
\hline 6 & $\mathrm{BA}_{30}$ & 30 & 15 \\
\hline
\end{tabular}

Keterangan:

$\mathrm{BN}_{1}=$ Beton Normal

$\mathrm{BA}_{10}=$ Beton dengan penambahan Fly Ash $10 \%$

$\mathrm{BA}_{15}=$ Beton dengan penambahan Fly Ash $15 \%$

$\mathrm{BA}_{20}=$ Beton dengan penambahan Fly Ash $20 \%$

$\mathrm{BA}_{25}=$ Beton dengan penambahan Fly Ash $25 \%$

$\mathrm{BA}_{30}=$ Beton dengan penambahan Fly Ash $30 \%$ 


\section{Hasil dan Pembahasan}

\subsection{Pengujian agregat}

Pengujian agregat yang dilakukan dalam penelitian ini meliputi pengujian kadar lumpur, kadar air, penyerapan, $\mathrm{Bj}$, dan modulus kehalusan serta keausan untuk agregat kasar, hasil pengujian dirangkum dalam Tabel 3.

Tabel 3 Hasil pemeriksaan agregat halus dan agregat kasar

\begin{tabular}{clcc}
\hline No & Pengujian & Agregat Halus & Agregat Kasar \\
\hline 1 & Kadar Lumpur & $0,50 \%$ & $0,50 \%$ \\
\hline 2 & Kadar Air & $3,00 \%$ & $0,75 \%$ \\
\hline 3 & Penyerapan Air & $3,60 \%$ & $1.5 \%$ \\
\hline 4 & Bj SSD & 2,38 & 2,46 \\
\hline 5 & Modulus Kehalusan & $2,68 \%$ & $7,16 \%$ \\
\hline 6 & Keausan & - & $29,40 \%$ \\
\hline
\end{tabular}

\subsection{Rancangan campuran}

Perencanaan campuran beton menggunakan metode SNI (Standar Nasional Indonesia). Perencanaan campuran beton terdapat penentuan kuat tekan yang direncanakan, jenis semen, umur beton, faktor air semen (FAS), kadar air bebas, ukuran agregat maksimum, berat jenis dan nilai slump. Mutu beton yang direncanakan yaitu beton $25 \mathrm{MPa}$, perhitungan tersebut menghasilkan kebutuhan bahan per $\mathrm{m}^{3}$ sebagai berikut:
a. Semen
$=427,0 \mathrm{~kg}$
b. Agregat kasar (batu pecah)
$=639,1 \mathrm{~kg}$
c. Agregat halus (pasir)
$=958,7 \mathrm{~kg}$
d. Air
$=205,0 \mathrm{~kg}$

\subsection{Pengujian slump}

Pengujian Slump dilakukan terhadap benda uji dan hasil pengujian slump ditunjukkan pada gambar 3 berikut ini:

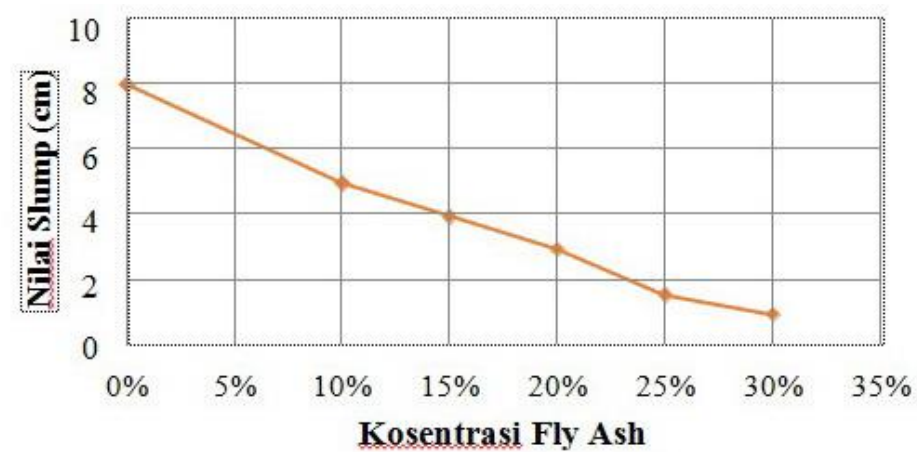

Gambar 3 Grafik hubungan slump dengan konsentrasi fly ash

Dari gambar 3 menunjukkan bahwa penambahan fly ash pada campuran beton dapat mempengaruhi nilai slump, semakin tinggi kadar fly ash yang ditambahkkan maka semakin rendah nilai slump yang diperoleh, hal ini dikarenakan penambahan fly ash pada campuran menyebabkan bertambahnya volume material yang menyerap air lebih besar (semen dan fly ash) tersebut dan 
mempengaruhi nilai FAS akibatnya adukan beton menjadi lebih kental atau kaku sehingga terjadi penurunan nilai slump.

\subsection{Kuat tekan}

Pengujian kuat tekan beton menggunakan Testing Machine dengan kapasitas $2000 \mathrm{kN}$ untuk mendapatkan beban maksimum yaitu pada saat beton hancur ketika menerima beban yang diberi oleh Testing Machine tersebut (Pmax). Pengujian ini dilakukan dengan tujuan untuk memperoleh nilai kuat tekan beton maksimum pada variasi penambahan fly ash yang dilakukan pada usia 28 hari. Hasil pengujian tersebut dapat dilihat pada Gambar 4.

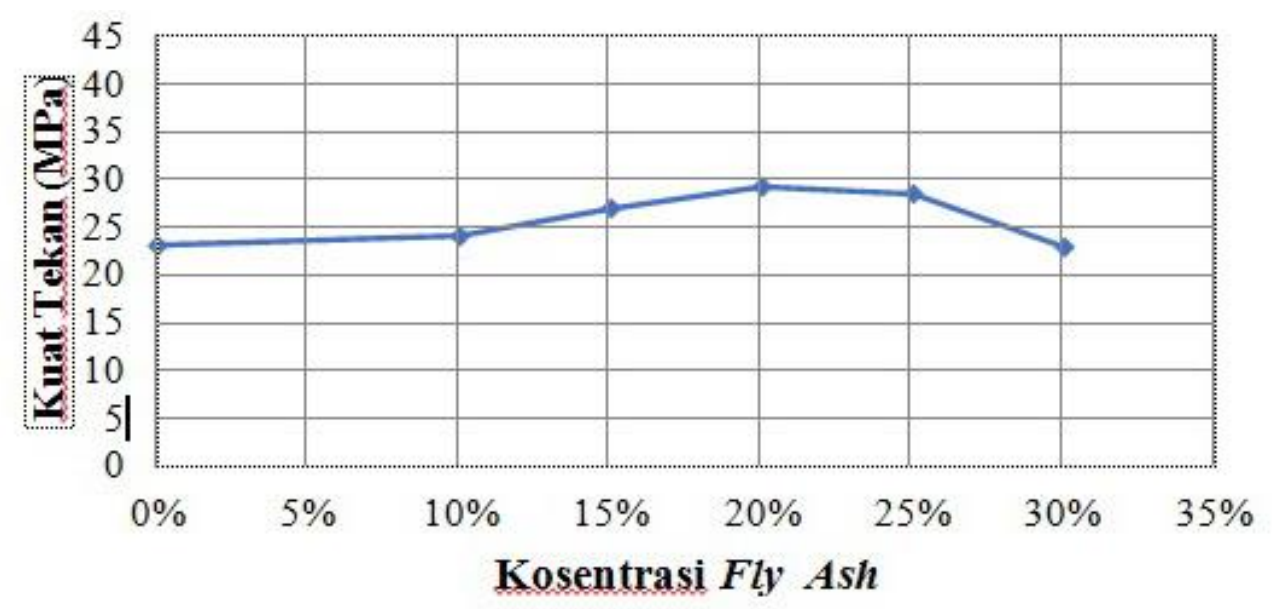

Gambar 4 Hubungan kuat tekan beton dengan presentase fly ash

Dari gambar 4 di atas dapat dilihat bahwa kuat tekan beton yang tertinggi terdapat pada komposisi campuran dengan variasi fly ash $20 \%$ yaitu sebesar 29,43 $\mathrm{MPa}$, kuat tekan beton menurun pada komposisi campuran fly ash dengan variasi $25 \%, 30 \%$ yaitu sebesar 28,66 MPa dan 23,09 MPa. Ini mengindikasikan bahwa penggunaan fly ash pada kadar tertentu sebagai bahan tambah dapat memperbaiki sifat mekanik beton.

\section{Kesimpulan dan Saran}

Penambahan fly ash pada campuran beton sangat berpengaruh pada nilai kuat tekan beton, hal ini dilihat dari nilai kuat tekan beton rata-rata kadar optimum pada umur 28 hari dengan variasi kadar fly ash 0\%, 10\%, 15\%, 20\%, 25\% dan $30 \%$ terhadap berat semen secara berturut-turut 23,28 Mpa, 24,24 MPa, 27,13 Mpa, 29,43 MPa, 28,66 Mpa dan 23,09 MPa. Nilai kuat tekan tertinggi terjadi pada variasi kadar fly ash 20\% sebesar 29,43 Mpa yang meningkatkan kuat tekan sebesar $26,45 \%$ dari beton tanpa fly ash.

\section{Daftar Kepustakaan}

Armeyn, 2014, Kuat Tekan Beton dengan Fly Ash Ex. PLTU Sijantang Sawahlunto, Jurnal Momentum 16(2):24-33. 
Crouch, L.K., Hewitt, R., Byard, B., 2007, High Volume Fly Ash Concrete, Prosiding World of Coal Ash (WOCA) :1-14.

Danasi, M dan Lisantono, A., 2015, Pengaruh Penambahan Fly Ash pada Beton Mutu Tinggi dengan Silica Fume dan Filler Pasir Kwarsa, Prosiding Konferensi Teknik Sipil 9:665-672, Makassar.

Engineering and Biotechnology (MMECEB 2015):113-116

Ervianto, M., Saleh, F dan Prayuda, H., 2016, Kuat Tekan Beton Mutu Tinggi Menggunakan Bahan Tambah Abu Terbang (Fly Ash) dan Zat Adiktif (Bestmittel), Sinergi 20(3):199-206.

Feng, J., Yu, L., Liu, Y. dan Ma, G., 2015, Influence of super-fine fly ash on the properties of concrete under steam curing condition, Proceeding $2^{\text {nd }}$ International Conference on Machinery, Materials Engineering, Chemical

Gopalakrishnan, R., 2018, Strength and Durability of High Volume Fly Ash Concrete in Severe Environment, International Journal of Civil Engineering and Technology (IJCIET) 9(11):718-727.

Jain, A. dan Islam, N., 2013, Use of Fly Ash as Partial Replacement of Sand in Cement Mortar, International Journal of Innovative Research in Science, Engineering and Technology 2(5):1323-1332.

Marthinus, A.P., Sumajouw, M.D.J., dan Windah, R.S., 2015, Pengaruh Penambahan Abu Terbang (Fly Ash) Terhadap Kuat Tarik Belah Beton, Jurnal Sipil Statika 3(11):729-736.

Mulyono, 2004, Teknologi Beton, Andi, Jogyakarta.

Pujianto, A., 2010, Beton Mutu Tinggi dengan Bahan Tambah Superplasticizer dan Fly Ash, Jurnal Ilmiah Semesta Teknika 13(2):171-180.

Setiawati, M., 2018, Fly Ash Sebagai Bahan Pengganti Semen pada Beton, Prosiding Seminar Nasional Sains dan Teknologi:1-8.

SK. SNI S-15-1990-F, 1990, Persyaratan Mutu Abu Terbang Sebagai Bahan Tambahan Dalam Campuran Beton, Departemen Pekerjaan Umum, Yayasan LPMB, Bandung

SNI 2460-2014, 2014, Spesifikasi Abu Terbang Batubara dan Pozzolan Alam Mentah atau yang Telah Dikalsinasi untuk Digunakan dalam Beton, Badan Standar Nasional Indonesia.

Suarnita, I.W., 2011, Kuat Tekan Beton dengan Aditif Fly Ash Ex. PLTU Mpanau Tavaeli, Jurnal Smartek 9(1):1-10.

Tjokrodimulya, 1996, Teknologi Beton, Nafiri, Jogyakarta. 